\title{
Strengthening institutions theory on modification of technology acceptance model: A study of financial information system for local government
}

\author{
Fauzi and Citrawati Jatiningrum* \\ STMIK Pringsewu Lampung, Indonesia \\ *Correspondence email: citrawati1980@gmail.com
}

\section{ARTICLE INFO}

\section{- Research Article}

\section{Article History}

Received 23 February 2021

Accepted 14 March 2021

Published 26 April 2021

\section{Keywords}

public finance; local government; SIPKD; technology acceptance model

\section{JEL Classification E60; H83; M48}

\begin{abstract}
The financial information system for local Government or SIPKD regulation in Indonesia are mandatory. There have been several innovations on it, but in practice mostly they were not effective in term of user acceptance due to several obstacles. This study investigates the modified Technology Acceptance Model (TAM) theory proposed with the institutional strengthening theory on the user performance of SIPKD. Supported by the sample of 556 SIPKD users from the Lampung Provincial Government, the results showed that all constructs are associated in accordance with the theory and concept of TAM. The quality of training had a dominant effect on the ease of use and usefulness. Related to the reinforcement theory, the results showed that facilitating conditions and incentives affect the performance of SIPKD users. Meanwhile, institutional pressure did not show its role to improve the performance of users. The main findings revealed that the TAM model becomes more perfect when imbued with the reinforcement theory. These results suggest that information system acceptance is higher when reinforcement theory is able to manipulate the cognitive of users to further improve their individual performance.
\end{abstract}

To cite this article: Fauzi \& Jatiningrum, C. (2021). Strengthening institutions theory on modification of technology acceptance model: A study of financial information system for local government. Journal of Socioeconomics and Development, 4(1), 109-119. https://doi.org/10.31328/jsed.v4i1.2254

ISSN 2615-6075 online; ISSN 2615-6946 print (CUWG Press, 2021

\section{INTRODUCTION}

The formulating government and implementing state budget policies are obliged to be open and responsible for the entire results of development implementation (Yusuf, 2021). One form of responsibility is realized by providing comprehensive financial information to the wider community (Jerene \& Sharma, 2020). This condition can only be achieved with financial information system for local governments that utilize information technology advancements (Chen et al., 2016). The end result is an information system that is able to foster a clean, transparent government and is able to effectively respond to demands for change (Jerene \& Sharma, 2020; Carrera-Mora et al., 2019). Indonesian Ministry of Home Affairs through the Regional Financial Administration Agency in 2009 cooperated with a third party to create the Financial Information System for Local Government in Indonesia, referred to as SIPKD. The purpose of this system is for uniformity in the management of regional finances in all local governments in Indonesia.

SIPKD is an integrated application that is used as a tool for local governments to improve the 
effectiveness of the implementation of various regulations in regional financial management (Fauzi et al., 2019). SIPKD was developed on the information technology basis and was designed in such a way to be a means of collection, processing, presentation, and reference, as well as to process regional financial data/information communication among the Ministry of Finance, the Ministry of Home Affairs, Local Government, and owners or users (Sayekti \& Putarta, 2016; Carrera-Mora et al., 2019). Its application is based on the principles of efficiency, economicalness, effectiveness, transparency, accountability, and auditability. This application is also a realization of the facilitation from the Ministry of Home Affairs to local governments in the field of regional financial management. The main objective is to strengthen the common perception of systems and procedures for regional financial management, especially in interpreting and implementing various financial laws and regulations (Isaac et al., 2017).

SIPKD is applied in order to help to facilitate local governments in preparing the budget, implementing and administering accounting and reporting, as well as maintaining the accountability of APBD (regional budgeting) implementation. The aspect of legality for the presence of SIKD has been affirmed through Republic of Indonesia Government Regulation (PPRI) Number 56 of 2005 concerning SIKD. Halim et al. (2012) in their research showed that out of 524 local governments in Indonesia, 361 local governments (68.89\%) already used a financial information system. Meanwhile, 163 local governments (31.11\%) were not yet certain about the financial information system that they use. Halim et al. (2012) found a number of obstacles in implementing SIPKD. The biggest obstacle faced was the lack of readiness of human resources, by $30 \%$. Other technical obstacles related to the implementation of SIPKD were network problems $(29 \%)$, software $(11 \%)$, application $(12 \%)$, hardware $(8 \%)$, and other factors (10\%).

Furthermore, Davis (1985), Venkatesh \& Bala (2008), and Venkatesh et al. (2012) explained that user acceptance of technology is a factor that determines the successful use of technology. Technology Acceptance Model (TAM) is a theory that is widely used for research on human behavior in information technology. TAM eventually became the most influential theory in the field of SI. TAM model is considered more parsimonious to explain the behavior of the use of information system in an organizational context. TAM model separates cognitive and affective aspects by describing the construct of belief as a cognitive and affective aspect by describing the construct of belief as a cognitive aspect and attitude as an affective aspect (Darsono, 2005; Davis, 1985).

The successful application of information technology is inseparable from the role of users of information systems to accept systems developed or implemented in management (Chen et al., 2016; Venkatesh et al., 2012; Zhou et al., 2018). Previous researchers documented the integration TAM theory with several aspects, such as customer awareness factors and subjective norms. The main finding of the study stated that financial technology adoption is positively influenced by customer awareness, subjective norms, and perceived usefulness (Winarno \& Putra, 2020) on behavioral intention to use accounting information systems by school financial managers (Permatasari et al., 2018). TAM theory related to reputation has a significant influence on users of an e-finance platform (Zhou et al., 2018). Chandra (2015) focused on the impact of extended TAM with constructs (trust, enjoyment, perceived ease of use, and perceived usefulness) and the antecedent constructs (security, time consumption, economic gain, and playfulness).

Meanwhile, Seddon (1997), Sayekti \& Putarta (2016), and Zhou et al. (2018) stated that individual performance is the opinion of users of specific application systems that are used to improve their performance within the organization. One of the expected concepts of TAM theory is the strengthening theory, which is a theory that specifically addresses actions to manipulate behavior. This reinforcement theory forms certain behaviors (behavior shaping) since theoretically the consequences of actions need to be regulated, depending on the goals of the actors (Fauzi et al., 2019). This theory is used to design changes in human behavior in organizations. A type of behavior of an employee can be designed to occur repeatedly to behave positively by stimulating employees with certain stimuli (which reinforce certain behaviors). Similarly, a type of negative behavior can be removed with certain certain stimulus (which weakens certain behaviors). Strengthening theory ignores feelings, attitudes, expectations and other variables that are known to influence behavior. Chau \& $\mathrm{Hu}$ (2001) stated that pressure from top management can have a positive influence on the acceptance of information systems. Gardner et al. 
(2009) has shown a double-edged sword pattern of pressure that can have positive or negative implications. In this case, the implication can be seen as an aspect of the quality of institutional pressure.

This study aims to examine the modification of the TAM theory when it is integrated with the strengthening theory. The expectation study provides a stimulus for SIPKD users. TAM modification with the strengthening theory include facilitating conditions, institutional pressure, and incentives. Venkatesh \& Bala (2008) and Venkatesh et al. (2012) showed that the condition factors facilitate a positive and significant effect on the use of information systems and information technology that ultimately improve individual performance. The said facilitating conditions and individual performance is in the context of utilizing information systems and information technology. The implementation of SIPKD which in the result is the output of SIPKD user performance is inseparable from the facilitating conditions. Those conditions can be in the form of an SIPKD usage guideline provision, assisting colleagues in the case of difficulties in implementing SIPKD, special assistants for SIPKD use, and systems responsive to fast-changing financial management regulations.

\section{RESEARCH METHOD}

This research is a cross-sectional study with the sample study SIPKD users or operators in the local government units (SKPD) in regencies/cities in Lampung Province. Sampling was carried out with such criteria as: civil servants, minimum level of education of high school graduates, experienced in using Microsoft Windows, Microsoft Word, and Excel. Based on the circular letter (SE) of the Minister of Home Affairs No. 900/122/BAKD in 2010, 171 local governments have implemented SIPKD. Lampung Province has 11 regional governments that have used SIPKD. In general, the SIPKD users indicate a homogeneous sample throughout Indonesia. Hence, regencies or cities in Lampung Province are selected as samples. The following is the number of research samples that fit the criteria (Table 1).

Table 1 shows the number of the distributed questionnaires, i.e. to 600 respondents. Returning questionnaires amounted to 571 questionnaires. All returned questionnaires were then checked first to identify the completeness of responses. It was found that 15 questionnaires were not complete, such as (i) incompleteness in filling out the questionnaire and/or the identity of the respondent, (ii) incorrectly filling out the questionnaire. Thus, the number of questionnaires that met the requirements or were suitable for processing was 556 questionnaires (92.7\%).

Table 1. Distribution of Respondents and Questionnaires by Region

\begin{tabular}{lrrrrr}
\hline & \multicolumn{4}{c}{ Questionnaire } & Per- \\
\cline { 2 - 5 } Regency/City & $\begin{array}{c}\text { Distri- } \\
\text { buted }\end{array}$ & $\begin{array}{c}\text { Recei- } \\
\text { ved }\end{array}$ & $\begin{array}{c}\text { Not } \\
\text { Accep } \\
\text {-table }\end{array}$ & Total & $\begin{array}{c}\text { cen- } \\
\text { tage }\end{array}$ \\
\hline 1. Lampung Province & 60 & 57 & 1 & 56 & 93.3 \\
2. Tulang Bawang & 60 & 58 & 2 & 56 & 93.3 \\
3. Lampung Tengah & 60 & 56 & 1 & 55 & 92.0 \\
4. Metro & 40 & 38 & 1 & 37 & 92.5 \\
5. Lampung Selatan & 60 & 57 & 1 & 56 & 93.3 \\
6. Bandar Lampung & 60 & 56 & 2 & 54 & 90.0 \\
7. Way Kanan & 60 & 59 & 1 & 58 & 96.7 \\
8. Lampung Timur & 60 & 58 & 2 & 56 & 93.3 \\
9. Tanggamus & 40 & 37 & 1 & 36 & 90.0 \\
10.Lampung Utara & 60 & 57 & 2 & 55 & 83.3 \\
11.Lampung Barat & 40 & 38 & 1 & 37 & 92.5 \\
\hline Total Sample & 600 & 571 & 15 & 556 & 92.7 \\
\hline
\end{tabular}

The research variables included perceptions, experiences, and supports received by SIPKD users and how they affected their performance (Table 2 and Figure 1). The conceptual framework of the relationship between variables is hypothesized as follows:

H1: Quality of training has a significant positive effect on perceived ease of use of SIPKD

$\mathrm{H} 2$ : Quality of training has a significant positive effect on the perceived usefulness of SIPKD

H3: Perceived ease of use e of SIPKD has a significant positive effect on the perceived usefulness of SIPKD

H4: Perceived ease of use of SIPKD has a significant positive effect on the attitude of the technology.

H5: Perceived usefulness SIPKD have a significant positive effect on the attitude of the technology

H6: Attitudes on technology have a significant positive effect on SIPKD user's performance

H7: Facilitating condition have a positive significant effect on SIPKD user's performance

H8: Institution pressure has a significant positive effect on SIPKD user's performance.

H9: Incentive has a significant positive effect on SIPKD user's performance 
Table 2. Variables and Definition of Variables

\begin{tabular}{|c|c|}
\hline Variables & Definition \\
\hline $\begin{array}{l}\text { Dependent: } \\
\text { User's Performance (Fauzi et } \\
\text { al., 2019) }\end{array}$ & $\begin{array}{l}\text { Performance is outcome resulted from the function of a particular job or activity during a } \\
\text { certain period, including individual psychological and organizational factors (Davis, 1985; } \\
\text { Hennessey \& Bernardin, 2003; Fauzi et al., 2019; Padilla-Meléndez et al., 2013). }\end{array}$ \\
\hline $\begin{array}{l}\text { Independent: } \\
\text { 1. Perceived Usefulness (PU) }\end{array}$ & $\begin{array}{l}\text { A person's level of confidence in the use of certain information technologies can further } \\
\text { improve their performance. Perceived usefulness three-question items adopted from (Davis, } \\
\text { 1985; Winarno \& Putra, 2020). }\end{array}$ \\
\hline 2. Perceived Ease of Use (PEU) & $\begin{array}{l}\text { It states the degree of confidence someone using a system or technology that can help } \\
\text { them from any difficulties to do, as adopted from (Davis, 1985; Winarno \& Putra, 2020; } \\
\text { Shyu \& Huang, 2011). }\end{array}$ \\
\hline 3. Attitude on Technology (AT) & $\begin{array}{l}\text { The attitude of individuals to use a system or information technology that already exists as a } \\
\text { representation of acceptance. This research leads respondents to state opinions and } \\
\text { evaluations related to technology (Davis, 1985; Fauzi, et al, 2019) }\end{array}$ \\
\hline 4. Training $(T)$ & $\begin{array}{l}\text { Training as an objective that employees achieve to master the knowledge, expertise and } \\
\text { behavior emphasized in training programs (García-Juan et al., 2019). The quality of training } \\
\text { is measured using indicators used by (Isaac et al., 2017). }\end{array}$ \\
\hline 5. Facilitating Condition (FC) & $\begin{array}{l}\text { Facilitating conditions are objective factors that exist in the environment that can make an } \\
\text { action easier to do (Venkatesh et al. 2012). The facilitating conditions questions consist of } \\
\text { three question items adopted from (Guerrero et al., 2018). }\end{array}$ \\
\hline 5. Institution Pressure (IP) & $\begin{array}{l}\text { The degree of pressure quality received by an employee from the institution (either through } \\
\text { official outside or internal supervisory). The indicator used to measure institutional pressure } \\
\text { was adopted from Tarhini et al. (2016) and Winarno \& Putra (2020). }\end{array}$ \\
\hline 7. Incentive (In) & $\begin{array}{l}\text { Incentives are consequences obtained from taking an action. Incentives are additional } \\
\text { income (money, goods, etc.) given to increase workplace enthusiasm or as stimulant money. } \\
\text { The conceptions of output expectations are separated into performance expectations, and } \\
\text { personal expectations (Sayekti \& Putarta, 2016; Thoyib et al., 2012). }\end{array}$ \\
\hline
\end{tabular}

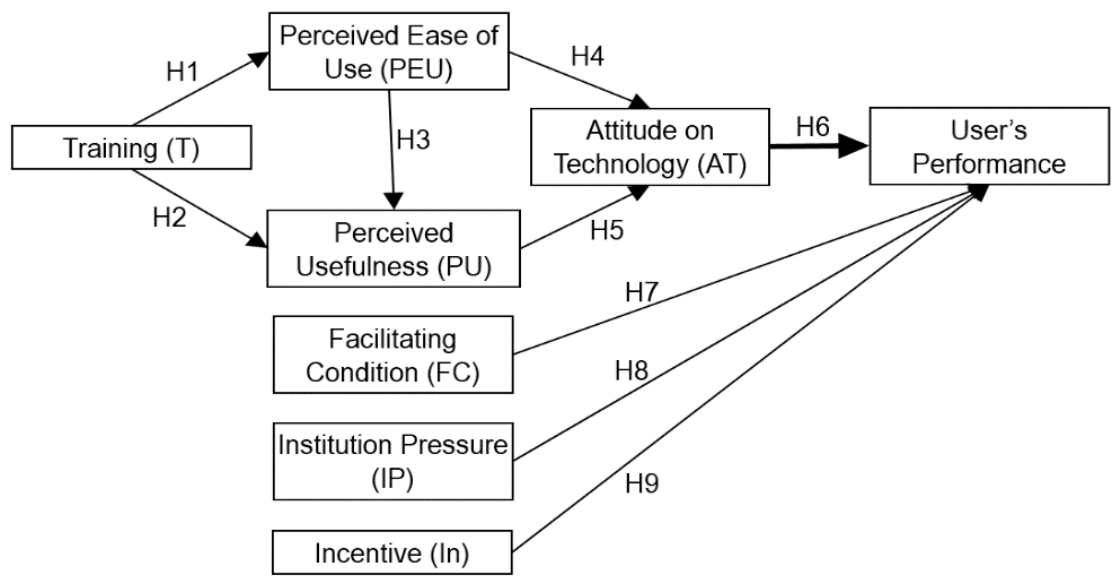

Figure 1. Conceptual framework of research

Testing in this study began with a test of validity and reliability. Leguina (2015) stated that validity is the level of scale or set of measuring instruments that are accurately able to represent the desired concept, whereas reliability is the level where the variable is consistent with what we are measuring. This study used the analysis of the suitability of the analysis method, namely the Structural Equation Model (SEM). Sarstedt et al. (2020) argued that SEM was chosen because it is more appropriate to examine the relationship between complex variables, examine the presence of unobservable variables or latent variables, and test the suitability of the model. This study tested the hypothesis with multiple regression analysis (multiple regression) by using SEM analysis as a test function simultaneously. Testing with SPSS was done to ensure the results of multiple regression analysis in which several independent variables were used to predict the value of the de variable independent (Gujarati, 2004). Below is the regression formula. 


$$
\begin{aligned}
P U= & a 0+\beta 1 T+\beta 3 P E U+e \\
P E U= & a 1+\beta 2 T+e \\
A T= & a 2+\beta 4 P U+\beta 5 P E U+e \\
U P= & a 3+\beta 6 A T+\beta 7 F C+\beta 6 I P+ \\
& \beta 6 I n+e
\end{aligned}
$$

The equation shows that perceived usefulness (PU) is affected by training $(T)$ and perceived ease to use (PEU); perceived ease to use (PEU) is affected by training $(T)$; attitudes on technology (AT) is affected by perceived usefulness (PU) and perceived ease to use (PEU); and user's performance $(P)$ is the function of attitudes on technology (AT), facilitating condition $(\mathrm{FC})$, institutional pressure (IP), and incentives (In). Meanwhile $a_{i}$ constant; $\beta_{i}$ coefficient and e error.

\section{RESULT AND DISCUSSION}

\section{Respondent Characteristics}

Table 3 presents the characteristics of the research respondents based on sex, years of service, education, and length of duty in SIKPD. Of all respondents (556), 310 people $(55.7 \%)$ were male and 246 people $(44.3 \%)$ were female. Characteristics of respondents based on their education levels is as follows. Respondents with a Bachelor's degree was the largest number, with 312 civil servants (56\%) of the total sample selected, while the senior high school graduates totaled to 138 civil servants (24.8\%). There were 56 respondents with Master's degrees (10.1\%) and 50 civil servants with 1-year upto 3-year Associate degrees (9\%).

\section{Model Specification}

The validity test results shown by the Pearson correlation value indicated that the question items for all significant variables were at the 0.01 level. The validity test results showed that the question items had an adequate level. The reliability test results were shown by Cronbach's Alpha values above 0.6. Therefore, all variables in the research model were reliable (Table 4).

Table 4 shows the result of the goodness of fit test. In general, the model is fit because three or more indicators exceeded the model's normative suitability. The measurement indicators were GFI (0.949), CFI (0.924), and chi-square with a probability of 0.000 . The results of all indicators were greater than the $\mathrm{t}$ value and therefore can be said to have an adequate level of conformity. Meanwhile, the results of AGFI test
(0.832) and TLI test (0.807) showed that the indicator values obtained were in the marginal suitability category. Thus, this test yielded good confirmation of the causality relationship.

Tabel 3. Respondent Characteristics

\begin{tabular}{lrc}
\hline Variable & Total & Percentage \\
\hline Sex & & $\%$ \\
$\quad$ Male & 310 & 55.7 \\
$\quad$ Female & 246 & 44.3 \\
Time of service & & \\
$\quad \leq 10$ years & 419 & 75.3 \\
$11-20$ years & 106 & 19.1 \\
$21-\quad 30$ years & 27 & 4.9 \\
$\quad$ 30 years & 4 & 0.7 \\
Education & 138 & 24.8 \\
$\quad$ High School & 50 & 9.0 \\
Associate Degree & 312 & 56.0 \\
Bachelor Degree & 56 & 10.2 \\
$\quad$ Others (Master's Degree) & & \\
Time of duty in SIPKD & 151 & 27.2 \\
$\quad$ < 1 year & 405 & 72.8 \\
$\quad>1$ year & &
\end{tabular}

Table 4. Result of Goodness of Fit Test

\begin{tabular}{lcc}
\hline Goodness of Fit Indices & Critical Value & Result Model \\
\hline$X^{2}-$ Chi Square & Small & 125.643 \\
Degree of Freedom (df) & & 11 \\
Probability & $\geq 0.05$ & 0.000 \\
Relative X & $\leq 2.00$ & 11.422 \\
(Cmin /DF) & & \\
GFI & $\geq 0.90$ & 0.949 \\
AGFI & $\geq 0.90$ & 0.832 \\
TLI & $\geq 0.95$ & 0.807 \\
CFI & $\geq 0.94$ & 0.924 \\
RMSE & $\leq 0.08$ & 0.137 \\
\hline
\end{tabular}

\section{Variable Relationship and SIPKD User's Performance}

All hypotheses tests used a structural equation model (SEM) application which included multiple regression. The test results the relationship between training quality and perceived ease of use ( $\mathrm{H} 1)$ showed that the influence of training quality had a positive effect on ease of use with a value of $B$ of 0.545 (Table 5). This result was statistically significant with a CR value of 15.313 at the level of $1.00 \%$. This indicates that there is an association between the quality of training and ease of use. In other words, the high quality of training can increase ease of use, and vice versa. Training is a process to develop employees' talents, skills, and abilities to complete certain jobs. High quality training can increase the degree of employees' confidence to use information which in 
turn can improve their work performance better and more efficiently. This finding supports the findings of Isaac et al. (2017) and Winarno \& Putra (2020).

Hypothesis testing the relationship between quality training and perceived usefulness $(\mathrm{H} 2)$ was obtained on the SEM calculation results. The analysis showed that the quality of training had a positive effect on usability with a coefficient $B$ of 0.409 with a t-value of 10.834. This result had a significance level of $5 \%$ because the t-value was greater than 1.96. Therefore, $\mathrm{H} 2$ is supported, meaning that the high quality of training is always able to improve the principle of usability for users. This finding is in line with Shyu \& Huang (2011) who suggested that the increase in learning provided by the government has a positive impact on the ease of use of information and the benefits felt by information users. These results are consistent with previous research showing that perceived usefulness has a positive and significant effect on the attitude of technology use (Fauzi et al., 2019; Winarno \& Putra, 2020).

The relationship between perceived ease of use and perceived usefulness $(\mathrm{H} 3)$ showed that ease of use had a positive effect on perceived usefulness with a coefficient of 0.342 with a significance value of $t$ value of 9.10 or significant at the $5 \%$ level. This study concludes that ease of use increases usability. The results of this study support prior studies (CarreraMora et al., 2019; Davis, 1985; Isaac et al., 2017) stating that there is a positive relationship between attitude to use and perceived usefulness.

Findings of the relationship between perceived ease of use and attitudes to technology ( $\mathrm{H} 4)$ showed that ease of use had a positive effect on attitudes toward technology with a coefficient $B$ of 0.334 and was statistically significant. From the test, it was found that the CR value was 7.508 with a significance level of $5 \%$ or above the t-value of 1.96 . This means that $\mathrm{H} 4$ is supported for attitudes towards technology. In other words, the high ease of use is able to improve attitudes towards technology for SIPKD users. This study confirms the results of Hennessey \& Bernardin (2003) and Tarhini et al. (2016) which stated that ease of use has a strong relationship to the attitude of information technology acceptance.

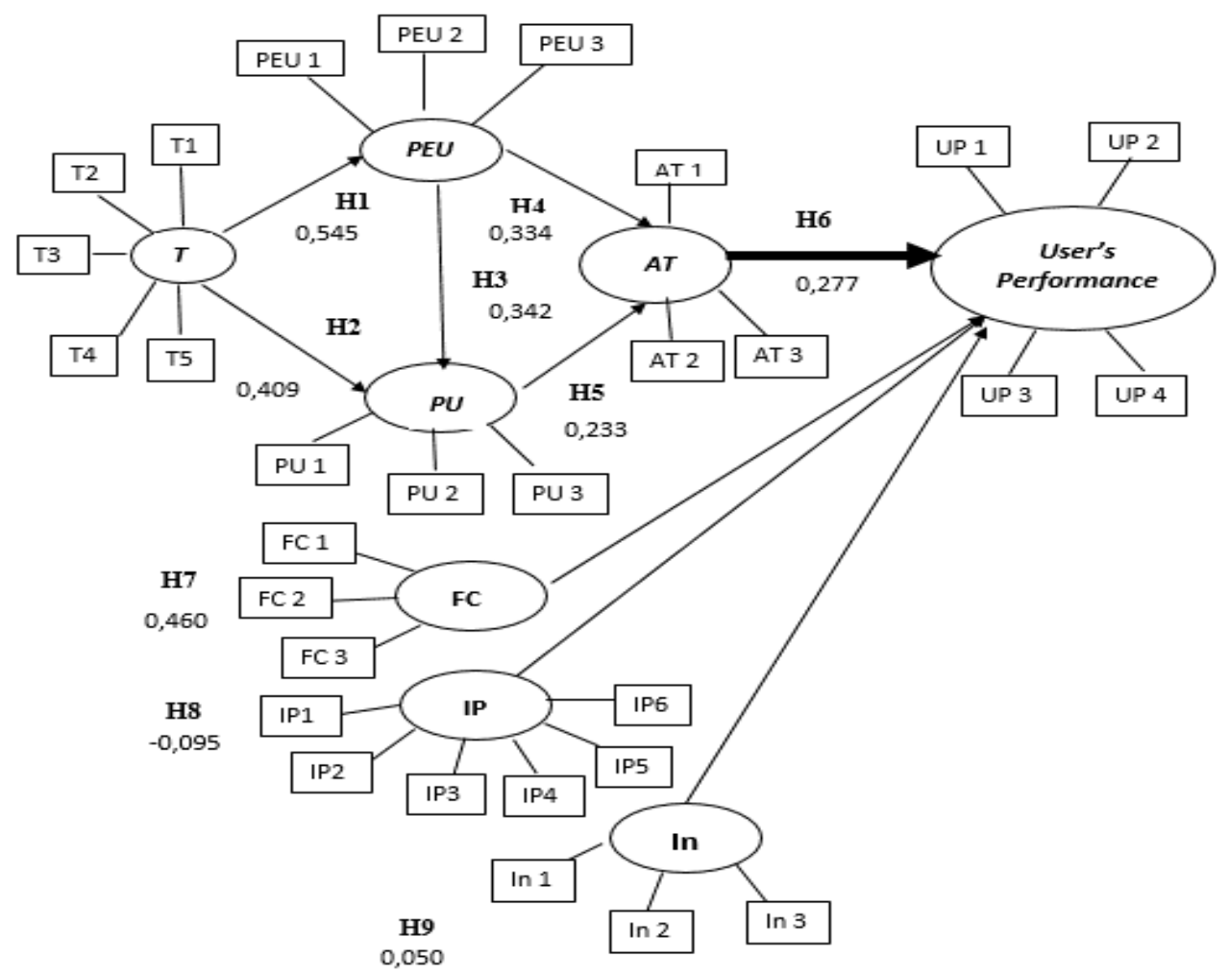

Figure 2. The estimated relationship among variables 
Table 5. Estimated Relationship among Research Variables

\begin{tabular}{lcc}
\hline Variable Relationship & Coefficient & \multicolumn{1}{c}{ t-value } \\
\hline Training (T) $\rightarrow$ Perceived Ease of Use (PEU) & 0.545 & $15.313^{* * *}$ \\
Training (T) $\rightarrow$ Perceived Usefulness (PU) & 0.409 & $10.834^{* * *}$ \\
Perceived Ease of Use (PEU) $\rightarrow$ Perceived Usefulness (PU) & 0.342 & $9.100^{* * *}$ \\
Perceived Ease of Use (PEU) $\rightarrow$ Attitude on Technology (AT) & 0.334 & $7.508^{* * *}$ \\
Perceived Usefulness (PU) $\rightarrow$ Attitude on Technology (AT) & 0.233 & $5.247^{* * *}$ \\
Attitude on Technology (AT) $\rightarrow$ User's Performance & 0.277 & $8.481^{* * *}$ \\
Facilitating Condition (FC) $\rightarrow$ User's Performance & 0.460 & $12.946^{* * *}$ \\
Institution Pressure (IP) $\rightarrow$ User's Performance & -0.095 & -2.944 \\
Incentive (In) $\rightarrow$ User's Performance & 0.050 & $1.562^{*}$ \\
\hline
\end{tabular}

For the relationship of use and attitudes to technology (H5), it was shown that usability had a positive effect on attitudes towards technology with a coefficient $B$ of 0.233 (Table 5). The value of the CR attribute was 5.247 , having a significance level of $5 \%$. This study concludes that $\mathrm{H} 5$ is supported. This finding is consistent with Chandra (2015), i.e. the high perception of usefulness will increase the attitude toward technology.

Furthermore, the relationship test of attitudes toward technology and user's performance of SIPKD (H6) stated that the attitude towards technology is related to user performance. The results of the SEM calculation analysis showed that the attitude toward technology had a positive effect on SIPKD user performance. The coefficient value $B$ was 0.277 with a CR value of 8.481 , statistically significant at level 5 . Thus, $\mathrm{H} 6$ is supported. This means that a high attitude towards technology can improve the performance of SIPKD users.

The results on the relationship between facilitating conditions and SIPKD user performance $(\mathrm{H} 7)$ showed that the facilitating conditions had a positive effect on the performance of SIPKD users with a coefficient $B$ of 0.46 , statistically significant at a significance level of $5 \%$. This study supports the hypothesis, meaning that the highly facilitating conditions can improve the performance of SIPKD users. In other words, facilities, infrastructure, and whatever features that support SIPKD users are able to create more performance in comparison with the absence of technological facilities and infrastructure. This finding is in line with Venkatesh et al. (2012) which revealed that facilitating conditions had a significant positive effect on information technology and information technology which could ultimately improve individual performance. However, the results of this study contradict those of Permatasari et al. (2018) and
Tarhini et al. (2016). Both studies stated that the relationship between the conditions that facilitate the performance of information system users was negative.

The results on the relationship between institutional pressure and SIPKD user performance (H8) showed that institutional pressure negatively affected the performance of SIPKD users. The test results had a coefficient $B$ of -0.095 , statistically significant at the $5 \%$ level with a CR value of $-2,944$. The results of this analysis were the opposite of what was hypothesized. Therefore, $\mathrm{H} 8$ is not supported. This means that the high institutional pressure reduces the performance of SIPKD users. In other words, institutional pressure that should be able to improve user performance apparently decreases SIPKD users' performance. This evidence shows that institutional pressure is not able to create SIPKD users' higher performance. This is not in line with the research conducted by Chandra (2015) and Darsono (2005). They found that high work pressure affects employee performance. The results of this study indicate that the pressure in the organization cannot fully improve the performance of SIPKD users. Venkatesh et al. (2012) stated that there is a positive relationship between conditions that facilitate the perception of usefulness and perceived ease of use.

The relationship between incentives and SIPKD user performance (H9) showed that incentives had a positive and statistically significant effect on the performance of SIPKD users, with the coefficient value $B$ of 0.050 and $t$-value of 1.562 at a significance level of $10 \%$ ( $t$-value of 1.282). This study still concludes that $\mathrm{H} 9$ is supported even though it is significant at the marginal level, meaning that the higher incentives are able to create the improved performance of SIPKD users. This also means that additional incentives will have consequences for increasing the performance of 
SIPKD users. Incentives are usually in the form of increased salaries given to an employee at one time specified in the form of a higher base salary. This reward is usually based exclusively on individual performance. This result is in line with the research conducted by Jordan et al. (2017) and Sayekti \& Putarta (2016).

\section{Research Implication}

The implication of this research is to contribute in the practice information systems or information technology application as required by the central government to local governments. Apart from the information system, other reliable factors must be considered, i.e. facilitating conditions, institutional pressures, and incentives that can manipulate the performance of system users. Therefore, in implementing the system, the authorities under the related ministries and the central government should pay attention to the standardized regulations to achieve their goals using the system.

Research implications for human resources development at the level of central government ministries and below is that they must take into account SIPKD users in implementing existing systems. Conditions that facilitate the development of Civil Servant Human Resources need to be applied. The career positions for system user operators are made in stages. This is so that system users or operators have a career in their work. Many SIPKD system users in the central and local governments seem to lose the notion that system users or operators are posts with no career path or position.

The results of this study also serve as input for the central government on the implementation of SIPKD since the following factors must be taken into account and implemented by local governments. First, the existence of quality training that can improve the usability of SIPKD and ease of use of SIPKD. This finding is supported by Dewi \& Wiratmaja (2020) and Fauzi et al. (2019) who proved that employee performance in terms of regional financial management is strongly influenced by the expertise of its users in using SIPKD. Therefore, government, especially regional ones, should continuously made efforts to provide training for SIPKD users. They are also expected to provide SIPKD usage training widely to all employees including new employees.

Second, SIPKD must be easy to use and useful as an accountability tool for regional financial management to lead to positive attitudes of SIPKD users. Permatasari et al. (2018) stated if the system implemented is believed to move users effectively, users believe that this system is easy to use so it does not require hard work to understand and use it. Users are sure that they will have no difficulty in using SIPKD, so that the desired goals can be achieved. Third, local governments are obliged to pay attention to the conditions that facilitate SIPKD users to perceive convenience and subsequently change the positive attitude of users. Isaac et al. (2017) stated that acceptance of information system quite successful in organizations while the organization emphasizes on providing facilities technology that will support users in the system usage.

Fourth, based on the research results, excessive institutional pressure on SIPKD users is not a good policy tool. Winarno \& Putra (2020) stated that practices in government information systems should be designed appropriately and systematically in the evaluation and work pressure to improve the performance of SIPKD users. For instance, Venkatesh \& Bala (2008) stated that collaborations and participation of users will create effective work in an organization.

Fifth, local governments need to pay attention to and increase the provision of incentives for SIPKD users so that they are all more motivated to improve individual performance and then organizational performance. Jerene \& Sharma (2020) proved that compared to incentives for high-performing users, it will be more useful to give incentives to the new users of the financial management system in the government. As potential SIPKD users will create more awareness and increase in performance, as a result, it may play an important role in improving financial system information technology in local government

The finding also implicates the government policy related to the Reporting of Budget Implementation Documents. It should be in accordance with the allotted time, as well as regional government financial reporting for one fiscal year (budget realization, balance sheet, cash flow statement, and notes to financial statements). Therefore, if the regional government is not timely in reporting either the document or the Regional government financial report, they must face sanctions imposed by the central government (Sayekti \& Putarta, 2016). The local government then strives to be timely in its reporting, namely by placing special emphasis or 
attention on users or SIPKD operators to comply with the rules set by the central government.

\section{CONCLUSION AND SUGGESTION}

This study empirically proved that the TAM modified with institutional strengthening theory (facilitating conditions, institutional pressure, and incentives) simultaneously had a positive effect on the performance of SIPKD users. This study used a survey method using respondents from SIPKD users in the SKPD of 11 local governments in Lampung province consisting of 556 respondents. The results showed that the performance of SIPKD users who had been supported by 140 good systems if modified with the concept of institutional strengthening was able to create or add individual motivation for SIPKD users to perform even higher. The study then concludes that the facilitating conditions and incentives can support the performance of SIPKD users. However, increasing institutional pressure did not affect the achievement of better performance for SIPKD users. This study suggests that institutional pressure does not affect performance because the punishment system for civil servants is still weak. Thus, it is necessary to evaluate the users and the policies made by the local government.

Regulation of financial management (Minister of Home Affairs Regulation) regarding SIPKD users must be scrutinized with appropriate policies. This policy encourages technical officers to show accountability appropriately to the treasurer. They are required to show performance to encourage their career at the institution. On the other hand, if someone's performance is not adequate, he needs to be subjected to sanctions for coaching in his future career.

This study has several limitations which need to be improved for further research. These limitations include (i) the sample of this study only used the Lampung provincial government, so future studies can extend their samples to all local governments in Indonesia; (ii) this study did not examine the respondents' subjective behavior control, whereas the theory of reasoned action and the theory of planned behavior that provide the foundation for the theory of TAM actually have the assumption that the users have high subjective behavior control.

\section{REFERENCES}

Alrajawy, I., Mohd Daud, N., Isaac, O., \& Mutahar, A. M. (2016). Mobile learning in Yemen public universities: Factors influence student's intention to use. The 7th International Conference on Postgraduate Education, Universiti Teknologi MARA (UiTM), Malaysia, 1 December 2016, 10501064.

Bangun, R., Theresia, L., Lahuddin, A. H., \& Ranti, G. (2018). The influence of culture, job satisfaction and motivation on the performance lecturer/employees. Proceedings of the International Conference on Industrial Engineering and Operations Management, 2541-2552. Retrieved from http://ieomsociety.org/ieom2018/papers/506.pdf.

Carrera-Mora, Ó., Ovando, C., Villafuerte, L., \& Parada, A. (2019). La relación de la perspectiva de eficiencia del ciudadano con su comportamiento de uso de los servicios de e-gobierno municipal. Innovar, 29(74), 133-146. https://doi.org/10.15446/innovar.v29n74.82096

Chandra, C. P. (2015). The adoption of e-auction in indonesia: the extended technology acceptance model study. iBuss Management, 3(2), 423-433. Retrieved from http://publication.petra.ac.id/ index.php/ibm/article/view/3770

Chau, P. Y. K., \& H, P. J. (2001). Information technology acceptance by individual professionals: A model comparison approach. A Journal of the Decision Science Institute, 32(4). https:// doi.org/10.1111/j.1540-5915.2001.tb00978.x

Cheema, U., Rizwan, M., Jalal, R., Durrani, F., \& Sohail, N. (2013). The trend of online shopping in 21st century: Impact of Enjoyment in TAM Model. Asian Journal of Empirical Research, 3(2), 131140. Retrieved from http://www.aessweb.com/pdf-files/131-141.pdf

Chen, M.-C., Chen, S.-S., Yeh, H.-M., \& Tsaur, W.-G. (2016). The key factors influencing internet finances services satisfaction: An empirical study in Taiwan. American Journal of Industrial and Business Management, 06(06), 748-762. https://doi.org/10.4236/ajibm.2016.66069

Darsono, L. I. (2005). Examining information technology acceptance. Gadjah Mada International Journal of Business, 7(2), 155-178. Retrieved from https://jurnal.ugm.ac.id/gamaijb/article/view/557 6

Davis, F. D. (1985). A technology acceptance model for empirically testing new end-user information systems: Theory and results. Sloan School of 
Management, Ph.D. Thesis. Massachusetts Institute of Technology. Retrieved from http://hdl.handle.net/1721.1/15192

Dewi, N. P. K. \& Wiratmaja, I. D. N. (2020). Pengaruh keterlibatan, kemampuan teknis, dan pelatihan kerja pemakai pada kinerja sistem informasi akuntansi. E-Jurnal Akuntansi, 30(4), 979-992. Retrieved https://doi.org/10.24843/eja.2020.v30.i04.p15

Fauzi, Irviani, R., Jatiningrum, C., Halim, A., \& Supriyadi. (2019). Financial management information system within government institution and supply chain strategy: Implementation Technology Acceptance Model (TAM). International Journal of Supply Chain Management, 8(3), 380-388. Retrieved from https://ojs.excelingtech.co.uk/index.php/IJSCM/ar ticle/view/3222

García-Juan, B., Escrig-Tena, A. B., \& Roca-Puig, V. (2019). The empowerment-organizational performance link in local governments. Personnel Review, 48(1), 118-140. https://doi.org/10.1108/PR-09-2017-0273

Gardner, R. M., Overhage, J. M., Steen, E. B., Munger, B. S., Holmes, J. H., Williamson, J. J., \& Detmer, D. E. (2009). Core content for the subspecialty of clinical informatics. Journal of the American Medical Informatics Association, 16(2), 153-157. https://doi.org/10.1197/jamia.M3045

Guerrero, S., Chênevert, D., Vandenberghe, C. Tremblay, M., \& Ben Ayed, A. K. (2018). Employees' psychological empowerment and performance: how customer feedback substitutes for leadership. Journal of Services Marketing, 32(7), 868-879. https://doi.org/10.1108/JSM-092017-0325

Gujarati, D. N. (2004). Basic Econometrics. McGraw Hill Book Company. New York. https://doi.org/10.1126/science.1186874

Halim, A., Jaya, W. K., \& Azis, N. (2012). Legalitas, Peluang, dan Hambatan Pembangunan Sistem Informasi Keuangan Negara dan Daerah (e-SIPKD) yang Terintegrasi. Kementerian Keuangan Republik Indonesia. Direktorat Jenderal Perimbangan Keuangan.

Hennessey, H. W., \& Bernardin, H. J. (2003). The relationship between performance appraisal criterion specificity and statistical evidence of discrimination. Human Resource Management, 42(2), $143-158$
Isaac, O., Abdullah, Z., Ramayah, T., \& Mutahar, A. M. (2017). Internet usage within government institutions in yemen: an extended Technology Acceptance Model (TAM) with internet self-efficacy and performance impact. Sci. Int.(Lahore), 29(4), 737-747. Retrieved from http://www.sciint.com/pdf/636367903853842652.pdf

Jamieson, R., Chase, J. P. M., \& Jamieson, R. (2003). TRITAM: A Model for Integrating Trust and Risk Perceptions in Business-to-Consumer Electronic Commerce. BLED 2003 Proceedings. Retrieved from https://aisel.aisnet.org/bled2003/60/

Jerene, W., \& Sharma, D. (2020). The adoption of financial technology in Ethiopia: a study of bank customers perspective. Journal of Banking and Financial Technology, 4, 53-63. https://doi.org/10.1007/s42786-020-00015-0

Jordan, G., Miglič, G., Todorović, I., \& Marič, M. (2017). Psychological empowerment, job satisfaction and organizational commitment among lecturers in higher education: Comparison of six CEE countries. Organizacija, 50(1), 17-32. https://doi.org/10.1515/orga-2017-0004

Kiraz, E. (2006). The Relationship between educational ideologies and technology acceptance in pre-service teachers. Journal of Economic Education, 9, 152-165. https://doi.org/10.15294/jeec.v7i2.27182

Larasati, N., Widyawan, \& Santosa, P. I. (2017). Technology readiness and technology acceptance model in new technology implementation process in low technology SMEs. International Journal of Innovation, Management and Technology, 8(2), 113-117. https://doi.org/10.18178/ijimt.2017.8.2.713

Leguina, A. (2015). A primer on partial least squares structural equation modeling (PLS-SEM). International Journal of Research \& Method in Education, 38(2), 220-221. https://doi.org/10.1080/1743727x.2015.1005806

Padilla-Meléndez, A., Del Aguila-Obra, A. R., \& Garrido-Moreno, A. (2013). Perceived playfulness, gender differences and technology acceptance model in a blended learning scenario. Computers and Education, 63, 306-317. https://doi.org/10.1016/j.compedu.2012.12.014

Permatasari, C. L. \& Prajanti, S. D. W. (2018). Acceptance of financial accounting information system at schools: Technology acceptance model. Journal of Economic Education, 7(2), 109-120. https://doi.org/10.15294/jeec.v7i2.27182 
Runi, I., Ramli, M., Nujum, S., \& Kalla, R. (2017) Influence leadership, motivation, competence, commitment to satisfaction and performance lecturer at private higher education Kopertis Region IX in South Sulawesi Province. IOSR Journal of Business and Manajement, 19(7), 5667. https://doi.org/10.9790/487X-1907075667

Sarstedt, M., Ringle, C. M., \& Hair, J. F. (2020). Partial least squares structural equation modeling. In: Homburg C., Klarmann M., Vomberg A. (eds) Handbook of Market Research. Springer, Cham. https://doi.org/10.1007/978-3-319-05542-8_15-1

Sayekti, F., \& Putarta, P. (2016). Penerapan Technology Acceptance Model (TAM) dalam pengujian model penerimaan sistem informasi keuangan daerah. Journal of Theory and Applied Management, 9(3), 196-209. https://doi.org/10.20473/jmtt.v9i3.3075

Seddon, P. (1997). A respecification and extension of the DeLone and McLean model of IS. Information Systems Research, 8(3), 240-253. Retrieved from https://pubsonline.informs.org/doi/abs/10.1287/is re.8.3.240

Shyu, S. H., \& Huang, J. (2011). Elucidating usage of e-government learning: A perspective of the extended technology acceptance model. Government Information Quarterly, 28(4), 491502. https://doi.org/10.1016/j.giq.2011.04.002

Tarhini, A., Elyas, T., Akour, M. A., \& Al-salti, Z. (2016). Technology, demographic characteristics and e-learning acceptance: A conceptual model based on extended technology acceptance model. Higher Education Studies, 6(3), 72-89. https://doi.org/10.5539/hes.v6n3p72
Thoyib, A., Taruno, S. C. Zain, D., \& Rahayu, M. (2012). Pengaruh gaya kepemimpinan terhadap kinerja dosen dengan kepuasan kerja dan motivasi kerja sebagai mediator (Studi pada Perguruan Tinggi Swasta di Jayapura). Journal Aplikasi Manajemen, 10(3), 504-509. Retrieved from https://jurnaljam.ub.ac.id/index.php/jam/article/v iew/434

Venkatesh, V. \& Bala, I. (2008). Technology Acceptance Model 3 and a research agenda on interventions. Journal of Decision Sciences Institute, 39(2), 273-278. https://doi.org/ 10.1111/j.1540-5915.2008.00192.x

Venkatesh, V., Thong, J. Y. L. \& Xu, X. (2012), Consumer acceptance and use of information technology: extending the unified theory of acceptance and use of technology. MIS Quarterly, 36(1), https://doi.org/10.2307/41410412

Winarno, W. A., \& Putra, H. S. (2020). Technology acceptance model of the Indonesian government financial reporting information systems. International Journal of Public Sector Performance Management, 6(1), 68-84. https://doi.org/10.1504/IJPSPM.2020.105089

Yusuf, M. (2021). The impact of local government accounting systems and performance- based budgeting on local government performance accountability. Jurnal Economic Resources, 3(2), 60-68. https://doi.org/10.33096/jer.v3i2.741

Zhou, W. (2018). What influence users ' e-finance continuance intention? The moderating role of trust. Industrial Management and Data Systems, 118(8), 1647-1670. https://doi.org/10.1108/IMDS-12-2017-0602 